\title{
O DEBATE EM TORNO DA MEDICINA EXPERIMENTAL NO SEGUNDO REINADO
}

\author{
THE DEBATE ON EXPERIMENTAL \\ MEDICINE UNDER THE SECOND REIGN
}

Flavio Coelho Edler*

EDLER, F. C.: 'The debate on experimental medicine under the second reign'. História, Ciências, Satide — Manguinhos, III (2):284-299, Jul.-Oct. 1996.

Although Brazil's twentieth century medicine was strong in the clinical tradition, this was no structural barrier to innovations from the realm of laboratory experiments, contrary to what some historians have argued. The broad debate over the rules of 'experimental methods' reveals a dimension of the struggle waged between proponents of rival medical theories, within a context where dissension among physicians threatened their scientific authority vis-â-vis that of other types of healers.

KEYWORDS: experimental medicine, bistory of medicine, history of Brazil.

* Pesquisador da Casa de Oswaldo Cruz/Fiocruz. Av. Brasil, 4365 Rio de Janeiro - RJ 21040-360
"Que resultados grandiosos para o comércio, para a indústria, para a agricultura, para o engrandecimento de nossa pátria, se todas essas atividades recebessem a consagração do método experimental" (Gazet. Méd. Braz., 1882).

"Cumpre ainda observar não seja a experiência tida num sentido tão exclusivo como admitem muitos filósofos, que fazem nela consistir toda a medicina.

Pesando, pois, devidamente os fatos observados, os recursos da arte diante das dificuldades insuperáveis, que se lhe antolham, cumpre ser prudente e não se deixar levar pelo entusiasmo até certo ponto dominante da nossa época, por essa injusta sofreguidão em abraçar sem reparo refletido as doutrinas prometedoras, o que é em grande parte efeito da credulidade vulgar" (dr. Moncorvo, 1874, p. 192).

A partir da década de 1870 , o dissenso em torno dos fundamentos epistemológicos do saber médico, que caracterizara o panorama da medicina acadêmica na primeira metade do século XIX, começou a se alterar em alguns aspectos fundamentais. Uma nova representação dos fundamentos do saber médico, expressa pela noção de 'medicina experimental', passou a conquistar adeptos principalmente entre a geração de médicos mais jovens. Devido sobretudo ao trabalho de persuasão política dos grupos que se articulavam em torno do reduzido número de 
1 Ver sobre a profissionalização da medicina no periodo do Segundo Reinado e sua correlação com as transformações epistemológicas do saber médico europeu contemporâneo, Edler (1992). Para uma análise semelhante sobre as controvérsias científicas no campo médico, num período anterior ao analisado por nós, ver o trabalho recém-concluído de Ferreira (1996). periódicos, a medicina brasileira aproximou-se dos mais recentes trabalhos médicos produzidos nos centros científicos do Velho Mundo e da América do Norte. Dessa forma, difundia-se a crença de que a competência atribuída à medicina nos países que nos serviam de modelo devia-se, fundamentalmente, às reformas promovidas nas instituições voltadas à pesquisa e ensino médicos, o que resultou na ampla reforma do ensino médico de 1879, inspirada no modelo germânico. ${ }^{1}$

Este período que antecede à Belle Époque da medicina, simbolizada pelas conquistas da era pastoriana, tem sido objeto de interpretações controversas por parte da historiografia especializada. Neste artigo, queremos enfatizar uma dimensão 'esquecida' do amplo movimento através do qual foram sendo erigidos o prestígio do médico, como detentor de um saber especializado, e a crença inabalável no poder preventivo e curativo da medicina 'científica', que tenderiam a se expressar por meio de representações de fundo cientificista, então prevalentes nos meios intelectuais.

A tese da contemporaneidade das controvérsias científicas desenvolvidas no meio médico brasileiro, em relação ao europeu, não é um ponto pacífico na historiografia relativa à medicina acadêmica brasileira. Mesmo alguns dos trabalhos mais recentes assumem, implicitamente, a hipótese da existência de uma defasagem qualitativa entre a espécie de saber médico cultivado nas sociedades burguesas industriais européias e aquele professado pelas academias da Corte e de Salvador. Uma suposta recusa dos postulados da medicina experimental pelas instituições médicas oficiais - onde reinaria a metafísica dos sistemas médicos - foi um argumento sustentado originalmente por Caldas Coni (1952, p. 34) para explicar as dificuldades de incorporação dos modelos institucionais definidos pelo padrão europeu.

Façamos, inicialmente, uma breve incursão na literatura especializada, destacando os critérios de periodização usados por alguns do autores que tentaram definir as fases que marcam a evolução da medicina no Império.

Os trabalhos pioneiros sobre a história da medicina brasileira foram redigidos quase que exclusivamente por médicos voltados para o passado de sua profissão, com a perspectiva de estabelecer uma certa memória que conduzia inexoravelmente à celebração da medicina vigente. O resgate dos fatos, personagens $\mathrm{e}$ instituições que se destinavam a lutar contra as doenças e a promover a saúde, na época colonial ou imperial, repousam geralmente numa narrativa de caráter bastante descritivo e esquemático.

Ao partirem de uma visão triunfalista da medicina contemporânea, definida como aquela cujo grau de eficácia é explicado 
2 Santos Filho (1977) e Nava (1947) apresentam uma periodização análoga.

3 Uma importante crítica, desenvolvida a partir de outra perspectiva, sobre as abordagens históricas na área da saúde coletiva no Brasil, encontra-se em Carvalho e Lima (1992). pelo padrão experimental dado à produção do saber e reificada pelo espaço do laboratório - erigido como o centro único de produção de verdades cientificamente elaboradas -, estes estudos traduzem explicitamente uma concepção evolucionista da ciência médica. Apresenta-se, assim, a história da medicina através de um esquema teleológico onde os valores e instituições que a caracterizam na atualidade são apreendidos como o corolário dos esforços individuais ou coletivos de remotos precursores iluminados, imbuídos dos desejos de introduzir a medicina experimental - entenda-se cientifica - em ambiente repleto de metafísica (Freire, 1968, p. 59). Ausente, entretanto, uma análise circunstanciada das relações concretas que se teceram entre a medicina acadêmica e aquela sociedade oligárquica, que permita esclarecer como se articularam os conhecimentos e as práticas médicas, mediados pelas instituições em diferentes conjunturas. ${ }^{2}$

A partir de meados da década de 1970, surgem novos estudos elaborados por historiadores profissionais ou cientistas sociais, destacando a problemática de correlacionar a produção do saber médico com o processo de constituição do Estado brasileiro. ${ }^{3}$ Dos estudos em questão, o trabalho de Luz (1982) é o que exige maior aprofundamento analítico, já que incide sobre muitas das questões que envolvem nosso tema, dando-lhes um tratamento com o qual nem sempre concordamos. Antes, porém, vale a pena uma menção ao trabalho anterior de Machado (1978), que também vai privilegiar um tipo de abordagem cujo traço comum àquela feita por Luz é a denúncia radical da ciência, que confunde seus usos com sua própria essência, transformando-a num ente dotado de projeto próprio.

A referida obra destaca o papel da medicina acadêmica na disciplinarização da população urbana do Império. Através de um "conjunto de teorias, políticas e práticas que se aplicam à saúde e bem-estar da população" - apreendidas pelo conceito de 'polícia médica' - o autor analisa o tipo de poder que a medicina social implica necessariamente. Fortemente influenciado pelos estudos de Michel Foucault, este trabalho tenta aplicar à sociedade patriarcal e escravista brasileira um enfoque que se revelou pouco apropriado, posto que carente de base empírica. Tomando como dado relevante da realidade o que não passava de um projeto defendido por segmentos da corporação médica, e com expressão apenas residual nas instituições que sustentavam o poder da classe senhorial, ele vai afirmar que a partir de 1850 , quando a criação da Junta Central de Higiene Pública esvazia o poder das câmaras municipais, "a medicina ocupa uma posição central no saber e seus braços sustentam a sociedade. $O$ projeto médico defende e justifica uma sociedade medicalizada, lutando 
${ }^{4}$ A genealogia social das teorias científicas é expressamente defendida pela autora quando afirma não se tratar "como se pensa geralmente de um conhecimento elaborado a priori, olimpicamente, que daria origem a um conjunto de práticas que poderiam eventualmente degenerar em distorções (mas, ao contrário, tratase)" de práticas ... sobre as quais se construíram modelos de conhecimento" (Luz, 1982, p. 17). por uma posição em que o direito, a educação, a política e a moral seriam condicionadas a seu saber" (op. cit., p. 190).

Luz, por sua vez, partindo da tese de que a diversidade de modelos científicos reproduzidos nas diversas instituições médicas do Império vinculava-se à origem social e às referências políticas dos movimentos que se organizavam em torno da questão da saúde, adota uma perspectiva construtivista macrossociológica para a medicina brasileira daquele período. ${ }^{4}$

Esta perspectiva conduziu-a a encarar a Academia Imperial de Medicina (AIM) como porta-voz de um único modelo de conhecimento hegemônico na medicina do Império. Em contraposição, os trabalhos desenvolvidos pela Escola Tropicalista Baiana - que, segundo a referida autora (1992, pp. 103-4), nunca teve seus postulados científicos incorporados ao discurso oficial da época - indicariam outra articulação saber/prática, uma outra defesa de interesses, e a necessidade de outra ordem política, refletindo o antagonismo existente em sua base social. Assim, a teoria miasmática sobre a causa das doenças seria imanente àquela sociedade escravista e agroexportadora, hegemônica, portanto, nos aparelhos ideológicos do Estado: na AIM, na Junta Central de Higiene Pública e nas faculdades médicas da Corte e da Bahia. O modelo da medicina experimental e biologicista, centrado numa etiologia ontológica, defendido pelos adeptos da Escola Tropicalista Baiana, revelaria, por outro lado, os interesses dos grupos sociais subalternos, capitaneados pela emergente burguesia industrial baiana (idem, ibidem, pp. 129-30).

Um outro trabalho ainda mais recente (Pires, 1989, p. 81) chama a atenção para o considerável atraso da medicina brasileira do século XIX, "em relação aos resultados obtidos pela humanidade em outros países":

"As doenças eram vistas como causadas pelo meio ambiente, sem uma explicação racional, experimental ou demonstrativa de como evoluem ... . É o saber de base metafísica que predomina no ensino e na prática médica até o final do século ... . (isto acontecia num momento em que) o microscópio, a prensa e o telescópio já eram uma realidade; a circulação sanguínea e as células nervosas já eram conhecidas pelos homens, e Descartes e Newton já utilizavam a ciência objetiva na física e na matemática."

O saber médico hegemônico no Brasil imperial seria, portanto, "basicamente a continuidade da reprodução do conhecimento dominado pela Igreja Católica, na Idade Média na Europa e mais tardiamente em Portugal e Espanha" (idem, ibidem, p. 104).

Estas afirmações carecem de respaldo empírico. Basta, para contradizê-las, observar que as disciplinas básicas das faculdades, como a física ou a química, seguiam o programa do ensino médico 
5 Dentre as aplicações da física médica clestacamos: as consideraçôes meteorológicas que influem sobre a saúde e o desenvolvimento das moléstias; efeitos da pressão atmosférica sobre a economia (humana) etc. (Figueiredo, 1874). francês contemporâneo. ${ }^{5}$ A surpresa que causam estas idéias ao leitor a par das polêmicas que envolviam a ciência médica européia no período oitocentista deve-se ao fato de Pires (op. cit.) ter levado às últimas conseqüências as interpretações tradicionais, que afirmam estar a medicina acadêmica do Império cindida entre dois modelos de conhecimento.

Desse modo, duas idéias devem ser revistas: em primeiro lugar, o preconceito difundido pelo positivismo comtiano, de que a medicina científica é aquela elaborada somente no espaço do laboratório, através do método experimental criado por Claude Bernard. Tal raciocínio conduz ao menosprezo de uma série de pesquisas realizadas pelos médicos brasileiros, desde o início do século XIX, visando o conhecimento do estado sanitário de determinadas regiões, que se traduziram em uma série de monografias sobre as febres nas cidades (Nava, 1949, pp. 40-6).

Na realidade, o pressuposto de que as doenças eram provocadas pelas condições atmosféricas e telúricas obrigava os médicos a reivindicar um certo programa de pesquisas sobre a nosografia nacional, associado a um levantamento topográfico. Isto era feito com o emprego dos métodos desenvolvidos pela disciplina denominada climatologia médica, como observa Ferreira (1996). Outras pesquisas que se associavam às deste tipo eram as análises químicas das fontes de água mineral, os estudos químicos sobre as propriedades terapêuticas das plantas nacionais - visando constituir as bases da matéria médica brasileira - e as importantes descrições de casos clínicos e tipos de tratamento, que os médicos publicavam, tendo como referência sua prática profissional. Uma fonte inestimável onde é possível encontrar o tipo de investigação levada a cabo por alguns médicos da Corte, antes do período que estamos analisando, é a Gazeta Médica do Rio de Janeiro (186264), além das Teses da Faculdade de Medicina do Rio de Janeiro.

Igualmente equivocada é a suposta divisão do saber médico entre dois modelos apresentados como estanques e contrapostos, representativos de dois tipos de mentalidades: o miasmático (metafísico), e o apoiado no paradigma da etiologia específica (científico). Tal contraposição falseia a complexa constelação de problemas práticos e teóricos que envolvia a medicina acadêmica no século XIX. Ainda que aceita, seria necessário esclarecer que tal divisão reportava-se a apenas uma das questões afetas aos esculápios: a que se referia à explicação sobre a origem, patogenia e etiologia das doenças. Para que se tenha uma dimensão real desta controvérsia no contexto da emergência da medicina experimental, basta lembrar que o advento da fisiologia, como disciplina autônoma em relação à anatomia clássica, bem como seu desenvolvimento de Bichat a Claude Bernard, fez-se inicialmente sem referência e posteriormente em oposição to para- 
${ }^{6} \mathrm{O}$ artigo de Derby foi traduzido recentemente para o português e publicado pela revista Ciência Hoje, vol. 10 (59), pp. 18-21. digma da causalidade ontológica das doenças (Canguilhem, 1977, pp. 59-62). Por outro lado, esta maneira de colocar o problema traduz implicitamente uma concepção linear e cumulativa do desenvolvimento do saber científico, que cada vez mais a história e a sociologia das ciências vêm rejeitando (Chalmers, 1994).

Encontramos, assim, um denominador comum entre as diversas abordagens apresentadas. Trata-se do critério de periodização da medicina no Brasil, baseado numa concepção positivista da evolução histórica. A distinção entre uma etapa predominantemente metafísica do saber médico oficial, no século passado, seguida por outra, científica, fundada em fatos positivos e no método experimental é aceita inclusive por aqueles autores que se pretendem críticos radicais do positivismo.

Antes de passarmos à apreciação da crítica epistemológica que os médicos do período faziam à concepção ingênua daqueles que depositavam uma fé irrestrita na medicina experimental, reforcemos o argumento sobre a contemporaneidade do saber médico brasileiro, diante da medicina européia.

Muitos dos depoimentos usados pela historiografia da medicina brasileira para corroborar a 'tese da defasagem' são testemunhos deixados por médicos que lutavam pelas reformas na legislação sanitária e no ensino médico, condenando o caráter livresco, superficial, doutrinário e escolástico — para usar alguns dos adjetivos empregados à época - do saber veiculado pelas academias. É preciso, entretanto, compreender o significado real destas opiniões emitidas pelos próprios professores das faculdades. Elas visavam atingir o governo imperial, que se mantinha negligente em relação às reformas reclamadas havia décadas pelas elites médicas. Ao mesmo tempo, tentavam denunciar o caráter meramente consumidor e passivo, mas não genericamente distinto, da medicina acadêmica brasileira em relação ao movimento científico que empolgava a Europa. Esta é, por exemplo, a compreensão revelada por Orville Derby (1852-1915) em artigo publicado no início de 1883 pela revista Science, no qual afirmava que "se o progresso científico brasileiro for lento não será por indiferença ou ignorância da verdadeira natureza da ciência, mas porque o desenvolvimento material do Império não oferece as facilidades de pesquisa desfrutadas em países mais velhos e mais ricos". 6

Um comentário semelhante foi atribuído pelo lente de anatomia patológica, Cipriano de Freitas (1853-1925), ao fisiologista Louis Couty, professor de fisiologia da Escola Politécnica. Referindo-se à ilustração da "classe médica no Brasil", Couty teria afiançado "que as obras de Claude Bernard e outros professores são tão conhecidas no Brasil quanto na França" (Freitas, Conferência de 26.8.1880).

Dois anos antes, em editorial assinado pelo médico helmintologista Julio de Moura na Revista Médica (1878, p. 114), por 
7 Benchimol (1995) apresenta minucioso estudo sobre a importação das idéias pastorianas em fins do século XIX. Seus argumentos destroem as interpretações simplistas que imputam a Oswaldo Cruz o papel de demiurgo da bacteriologia brasileira, como o faz Stepan (1976), dentre outros. ocasião da morte de Claude Bernard, afirmava-se que: "não havia um só médico brasileiro que não admirasse, na carência de estudos práticos de que se ressente o ensino em nossas faculdades, os frutos proveitosos que sobre inúmeras questões de fisiologia se devem ao colosso intelectual que acaba de ser fulminado".

O estigma de mero consumidor de idéias científicas elaboradas no exterior, a incapacidade de acompanhá-las a partir de experiências próprias, a ausência quase absoluta de investigações originais nas áreas de ponta, enfim, uma cultura científica de cunho fundamentalmente livresco - o que não significa qualitativamente defasado - podem ser aquilatados pelo comentário arguto de Martins Teixeira (Conferência de 29.8.1880), professor de física médica, sobre os concursos realizados na Faculdade de Medicina da Corte: "Os tiroteios de opiniões nos concursos sobre tal matéria (fisiologia) faz parecer sempre vitorioso o que apresenta opiniões que garante serem chegadas pelo último paquete."

Mas se os médicos brasileiros do Segundo Reinado mostravamse a par das mais recentes novidades científicas realizadas no Velho Mundo, que razão especial pode explicar a existência de um consenso tão arraigado entre vários historiadores quanto à prevalência de um suposto ambiente metafísico? Acreditamos que tal caracterização deve-se ao impacto causado pelo paradigma pastoriano sobre as teorias médicas do século XIX, e à tradição empirista e positivista que marcou até recentemente a historiografia das ciências.

Os historiadores tradicionais da medicina asseveram que os trabalhos de Pasteur representariam um marco fundamental na refutação definitiva de certos mitos médicos do passado. A Teoria dos Germes, que para muitos representa a fundação da medicina científica (Bernal, 1969, p. 666), é geralmente apresentada como o resultado mais alvissareiro da aplicação do protocolo metodológico estabelecido por Claude Bernard. Fixa-se, desse modo, uma linha de continuidade entre a fisiologia bernardiana e as pesquisas bacteriológicas de Pasteur, através da reificação do método prescrito pela medicina experimental. Lembremos que o próprio Claude Bernard corroboraria esta visão, pois negava a possibilidade de revoluções ou sobressaltos entre as teorias científicas, desde que elaboradas em consonância com suas regras metodológicas (Canguilhem, 1977, pp. 59-60).

Desse modo, muitos estudiosos procuraram demarcar uma ruptura entre uma etapa pré-científica ou metafísica da medicina brasileira em relação a outra, científica, através de um recurso básico: de um lado foram colocados os espíritos supostamente retóricos, anticientíficos, isto é, aqueles que rejeitavam as teses pastorianas; do outro, os verdadeiros luminares da medicina experimental, Oswaldo Cruz à frente.? $\mathrm{E}$ claro que algumas polêmicas 
8 A defesa que Pedro Nava (1949, p. 43) fez do professor de clínica interna da Faculdade de Medicina, Torres-Homem (1837-87), em seu affair científico com seu colega de cátedra, o bacteriologista Domingos Freire (1842-99), é demonstrativa de um destes esforços voltados para a reabilitação de médicos que se viram proscritos do universo científico do século XIX, através deste artifício reducionista. surgiram entre memorialistas e historiadores que se empenharam em salvar do naufrágio histórico alguns dos mais célebres médicos do Império que polemizaram com os sectários das teses pastorianas. $^{8}$

Entretanto, a análise dos argumentos utilizados pelos médicos, que se opuseram total ou parcialmente às teorias parasitológicas e bacteriológicas, confirma o acerto da tese kuhniana, que afirma ser a nova ciência originada não do erro ou da superstição e sim da ciência antiga (Kuhn, 1978). O detalhado estudo de Benchimol (1995), sobre o contexto histórico de importação das teorias parasitárias das doenças, ressalta a ampla negociação que envolvia médicos brasileiros, adeptos e adversários das idéias de Pasteur, tendo como pano de fundo, além de outras variáveis, a luta pela obtenção do reconhecimento das instituições hegemônicas no cenário internacional. Além desta espécie de credencial, necessária para legitimar as querelas científicas nacionais, os debatedores baseavam-se numa idêntica imagem do método experimental, à qual apelavam na imputação recíproca de desvio na aplicação das regras da ciência.

Curiosamente, a rígida demarcação entre uma medicina metafísica e especulativa e outra, de cunho científico, pertence à retórica desenvolvida naquele processo de legitimação profissional, a partir dos argumentos fornecidos por Magendie, Claude Bernard e seus seguidores. Um dos médicos que reivindicaram, nas famosas Conferências da Glória, a reforma do ensino médico assim se pronunciava:

"O método experimental foi largamente inaugurado na Europa pela ciência francesa, mas enquanto Magendie o sustentava no Colégio de França, o novo meio de ensino foi revolucionar a Alemanha, onde, desenvolvendo-se de um modo prodigioso, elevou em quarenta anos esse país à primeira nação científica do mundo. Sem investigação experimental não há medicina científica possivel" (Carvalho, Conferência de 19.8.1880).

Da mesma forma se pronunciava o dr. Felício dos Santos ao afirmar num editorial da Revista Médica (1.7.1876) sua confiança irrestrita nas transformações operadas na medicina pelo método experimental:

"Enquanto as deduções da razão pura resolvem-se no mesmo círculo estreito, reproduzindo os monótonos e mesmo eternos einsolúveis problemas, magníficos faróis se acendem nas hordas do domínio experimental e a ciência positiva firma em sólidos sopedâneos [alicerces] o critério da verdade. As ciências naturais, origem do bem-estar e do estupendo progresso hodierno, estabelecerão o domínio do homem sobre a matéria. 
9 Memória Histórica da FMRJ vol. V, 67-68.

10 Edler, op. cit., no primeiro capítulo, trata deste período marcado pela rápida obsolescência dos sistemas méclicos herdados.
O método experimental retemperou-se. O seu caráter de passividade, de expectação antiga desapareceu: em vez de esperar paciente as descobertas do acaso ele armou-se de instrumentos, de aparelhos, multiplicou seus processos e levou o escalpelo às entranhas da natura matter, para surpreender os segredos da criação.

Hoje a medicina, extreme do espírito dogmático das teorias ocas do racionalismo, ressaibo da escolástica, e sacudindo o torpor da expectação hipocrática, dispondo do opulento arsenal das ciências naturais, tornou-se ciência vasta e complicada. A nossa legenda não é mais a observação e o registro dos fatos, mas a experimentação e o indefesso laboremos..."

Em contraste com a primeira metade do século XIX, isto é, quando os postulados de Magendie e Claude Bernard não passavam de uma promessa que pretendia revigorar as bases do saber médico e influir positivamente na sua prática, as elites médicas apresentam, agora, um panteão de luminares construtores da medicina científica (Revista Médica, 10.6.1873):

"Laennec instituindo a auscultação, Awenbrugger descobrindo e Piorry aperfeiçoando a percussão, Magendie e Claude Bernard fundando as bases sólidas da fisiologia experimental, Wunderlick e Traube estudando a termometria clínica, Virchow dissipando as trevas da anatomia patológica etc. bem atestam a verdade que emitimos."

Podemos estabelecer com maior precisão a receptividade alcançada, no último terço do século XIX, pelo novo ideal empirista e positivista de cientificidade estabelecido a partir da noção de medicina experimental, confrontando um discurso do visconde de Sabóia (1835-1909), proferido no ato de doutoramento dos alunos da Faculdade de Medicina do Rio de Janeiro, em 1883, com outro, produzido vinte anos antes, em circunstâncias semelhantes, pelo seu antecessor na direção daquela instituição, o conselheiro Jobim (1802-78).

Na primeira ocasião, em novembro de 1863 , Jobim discursara sobre aspectos da profissão médica, chamando atenção para o imperativo de firmar-se uma postura ética no seio da corporação médica prescrevendo a caridade e a liberalidade entre os colegas como uma necessidade ditada "pela boa política", num contexto em que "sabemos pouco, observamos mal e conjeturamos muito". "Jobim era um crítico feroz do ecletismo e do empirismo clínico como solução para os impasses gerados pela crise nos fundamentos da medicina acadêmica. Ele mostrava-se pragmático e consciente dos impasses inerentes às circunstâncias em que os estudos de fisiologia experimental não passavam de uma aposta que colocava em risco o status profissional. ${ }^{10}$ 
O discurso de Sabóia (1883, pp. 11-3), pelo contrário, refletia já a plena confiança nas sólidas bases do saber médico. Perante os formandos, o imperador e o ministro do Império, o diretor da faculdade afirmava que a medicina havia realizado "no último quartel do século progressos admiráveis que só podem ser negados, amesquinhados, ou ridicularizados por aqueles que não vêem proclamada e estabelecida a cura absoluta de toda e qualquer enfermidade". Assim, após proclamar o fim "da fase especulativa e doutrinária" no ensino médico e o início de um novo "estado verdadeiramente científico" ele concluía:

"Nunca compreendi estudo médico sem laboratório em que a objetividade dos fatos, que possam ser percebidos ou caiam debaixo de nossos sentidos, tenha a sua confirmação na análise e verificação experimental bem estabelecida em todas as fases do fenômeno, que se queira estudar ou conhecer.

Quem diz medicina diz implicitamente ciência do conhecimento das manifestações mórbidas ou anormais da vida nas diversas esferas da atividade orgânica. A medicina não fez senão progressos lentos e até duvidosos enquanto seu papel se reduziu a procurar o princípio das coisas ... em que a doutrina substituía a análise, e as concepções abstratas adiantavam-se à lógica dos fatos e à crítica experimental. Foi somente depois que se aplicou ao seu estudo o método e o processo indutivos e os instrumentos de precisão, que a vemos volver das regiôes do empirismo para elevar-se a um alto nível científico... .

Quando em lugar de perscrutar os fenômenos orgânicos e de apreciá-los sob o ponto de vista da causalidade ... os médicos, abandonando o método indutivo lançaram-se no mundo da metafísica, em indagações puramente escolásticas sobre a vida, discutindo se esta precedia ou era consecutiva à organização, não produziram também senão o animismo de Sthall e o vitalismo transcendental de Hahnemann!"

Mas não havia só exaltação fetichista das virtudes da medicina experimental. Excelentes argumentos foram produzidos dentre os médicos que viam como uma ingenuidade a adesão irrestrita de certos colegas aos novos paradigmas sobre a causalidade das doenças.

$O$ ataque mais comum aos fervorosos defensores das teorias parasitológicas e bacteriológicas visava a sua pretensão exclusivista. Um comentário neste sentido foi feito pelo editor da Revista Médica (31.8.1875), o famoso darwinista Miranda de Azevedo, em relação à conferência proferida em 1875 pelo então jovem Silva Araújo (1853-1900), na Escola da Glória:

"O doutor Silva Araújo, no decorrer do discurso, revelou muita disposição para a oratória e dotes para a tribuna, bem que ao mesmo 
tempo patenteasse imaginação por demais ardente e impetuosa para um médico que se dedica a investigações positivas da ciência... . Deixou-se levar pelo entusiasmo, a ponto de sustentar por vezes, no seu discurso, que o parasitismo explica uma série de moléstias, como o tétano, a hematúria, e todas as moléstias infecciosas e contagiosas."

A expressão 'investigações positivas', usada aqui por Miranda de Azevedo, não traz a marca de uma estrita ótica empirista, como é possível supor-se à primeira vista. Nas referências constantes à "ciência positiva" ou "fato positivo" o termo 'positivo' possui três significados básicos: em geral era usado no sentido de real, em oposição a quimérico; positivo tinha também a ver com preciso, em oposição a vago; por fim, num sentido axiológico designava um empreendimento útil, em contraposição a ocioso. A fé no puro indutivismo havia sofrido um forte revés, num contexto marcado por querelas científicas em áreas localizadas do saber médico, como as que opuseram, por décadas, contagionistas versus anticontagionistas. Nesse caso, por exemplo, cada corrente vinha acumulando evidências empíricas relevantes sem apresentar uma explicação satisfatória sobre a causa das doenças epidêmicas, dificultando, assim, a formação de um consenso corporativo sobre as medidas higiênicas consideradas, então, eficazes.

Num artigo publicado pelo jornal Archivo Médico em maio de 1874 , isto é, quatro anos antes de Pasteur apresentar na Academia de Ciências de Paris sua Teoria dos Germes, um médico tentava definir as diferenças entre as teorias contagiosas e infecciosas que disputavam a explicação sobre a etiologia das doenças. Antes, porém, ele alertava quanto a dificuldade de se estabelecer uma verdade definitiva, apelando apenas para as inferências indutivas:

"Baseando nossos estudos em fatos e na observação não damoslhe contudo o valor que se tem pretendido dar. Inegavelmente a observação é um elemento de grande valor para a resolução desses problemas; mas ela pode ser incompleta, os fatos erroneamente apreciados ou mal interpretados, e enfim as coincidências estão longe de ser raras. Todas essas circunstâncias podem ser a causa de grandes erros e são a origem das divergências, que cada vez mais extremam os contagionistas e infeccionistas.

Em qualquer moléstia, por uns reputadas contagiosas, de ambos os lados se invocam fatos para decidir a questão. Os fatos resolvem tanto a favor de uns como de outros, nada decidem, sua autoridade é nula, sendo portanto falso o pseudo-axioma: contra fatos não há argumentos.

Sem a intervenção do raciocínio, sem a dupla arma da lógica e dos fatos é impossível chegar-se a conclusões verdadeiras." 
Opiniões semelhantes, embora mais próximas à tradição empirista, foram emitidas pelo dr. Felício dos Santos, ao comentar uma polêmica científica envolvendo os médicos Pereira Guimarães e Moncorvo (Revista Médica, 15.3.1874), sobre a ação abortiva do sulfato de quinina, então muito empregado no combate às doenças:

"Esta questão só poderá ser resolvida pela experiência e essa ainda é insuficiente. A nossa ciência é toda experimental e nada ganha com discussões teóricas a priori. Cumpre confessá-lo humildemente embora riam de nós os adeptos do filosofismo (que) as ciências experimentais não têm outro meio para a descoberta além da observação. É o método analítico com todas as desvantagens e com todos os perigos. Desses o mais comum é sem dúvida O POST HOC ERGO PROPTER HOC."

A crítica sustentada pelo visconde de Sabóia em 1883 (pp. 20-4) contra os partidários de Pasteur revela a um tempo não apenas seu respeito aos princípios metodológicos postulados pela "medicina experimental", como deixa explícito o fato de que a polêmica opunha paradigmas explicativos distintos e não modelos epistemológicos divergentes. Deixemos a palavra com o diretor da faculdade:

"Não tem deixado de aparecer doutrinas que tentam explicar todos os fenômenos dessa entidade mórbida (inflamação), e não ignorais também que, não satisfeitos com os conhecimentos que a ciência apresenta a respeito, alguns médicos e patologistas, com afã e ânsia quase vertiginosa, têm estudado nestes últimos anos o mundo dos infinitamente pequenos e procurado ali a origem e causa dos estados febris; a descoberta do micróbio do carbúnculo, o do chólera das galinhas, por Pasteur, foi um grito de alarma para que todos quisessem ser o Colombo de um novo micróbio, de modo que hoje não há estado febril grave ou moléstia de natureza zimótica ou epidêmica e mesmo cura difícil ou impossível, que não se queira atribuir aos micróbios ... .

Sem negar a grande vantagem das pesquisas tendentes ao conhecimento da origem e causa de certas moléstias ..., creio, entretanto, que muitos médicos nessas pesquisas vão se esquecendo de regras e preceitos da ciência experimental tão bemfundados por Magendie e aperfeiçoados por Claude Bernard; deixando um pouco de lado o estudo minucioso das alterações orgânicas, quer morfológicas, quer químicas, para se abalançarem nesses excessos de generalização de uma só causa para muitas moléstias diversas, em procura da glória que poderá esvair-se no fumo das decepções da vida, com prejuízo, entretanto, do caráter de seriedade que deve revestir as ciências médicas... . 
11 As precauções apontadas por Sabóia devemse em grande parte ao clima de euforia que se criara em torno dos trabalhos do prof. Domingos Freire (184299). Souza Lima (18421921), lente de higiene da mesma faculdade $e$ presidente da AIM no exercício de 1883 e 1884, combatia Freire asseverando sua inconformiclade com: "a velha e cômoda sentença de que contra fatos não há argumentos. Não há proposição mais banal, enquanto os fatos não forem bem observados, e convenientemente interpretados, de nada valem, e não poderão constituir base ou princípio irrefragável de argumentação" (Lima, 1884, p. 131).
O sábio Pasteur, a quem todos querem imitar - o que não censuro, e antes aplaudo - , quando resolveu por um modo admirável a questão microbiana do carbúnculo, tratou de elucidar todas as questões relativas à produção do calor no organismo; mas apesar disso, não foi ultimamente contestado por Koch em Berlim a exatidão dos fatos tão engenhosamente indicados por Pasteur?"

Sabóia (1835-1909) queria alertar neste discurso para os formandos de 1883 sobre os riscos de um tipo de ilusão cognitiva semelhante àquela que Bacon designara por idola theatri. ${ }^{11}$ Por isso sentenciara que "deduzir do desconhecido ou hipotético para o conhecido, se pode ser, algumas vezes, o facho temerário de uma experiência feliz será quase sempre um método perigoso nas pesquisas científicas".

\section{Conclusão}

Vimos aqui que a associação entre ciência médica e progresso material expressou-se por meio de um discurso triunfal que hoje, retrospectivamente, podemos qualificar como ingênuo. Mas, ao contrário do que em geral se supõe - e os depoimentos dos médicos brasileiros empenhados na institucionalização das disciplinas experimentais o comprovam -, o discurso marcado pela reificação do método experimental pertencia mais à retórica voltada à afirmação profissional do que às convicções profundas daqueles homens.

O exame das controvérsias geradas entre os adeptos e adversários das teorias médicas concorrentes revela que os mais argutos ridicularizavam os exageros do empirismo, impugnando as certezas dogmáticas dos mais afoitos adeptos do experimentalismo. Se os médicos-cientistas renunciaram de uma vez para sempre ao mito do experimentum crucis, capaz de garantir por si só a veracidade de um princípio científico, sabiam, entretanto, que o controle empírico das teorias se tornara fundamental para o avanço do conhecimento.

Se, por um lado, é necessário distinguir entre o discurso voltado para a legitimação profissional, baseado numa representação mística da medicina experimental, daquele que constituía parte de um argumento científico - bem mais consciente das limitações da experimentação no processo de elaboração do saber -, é preciso, por outro, explicar o porquê da convivência entre discursos opostos sustentados muitas vezes pelos mesmos indivíduos. A resposta, acreditamos, está na raiz de outro fenômeno conexo: a construção simultânea de uma imagem 'pura' e outra 'utilitária' da ciência, que não conflitavam. De fato, a profissiona- 
lização da medicina colocava em questão o problema de se alcançar seu reconhecimento público como sistema perito e, ao mesmo tempo, manter sua autonomia e status. Essa busca da autonomia institucional e disciplinar teve como contrapartida o desenvolvimento de um controle social interno que gerou não apenas a necessidade de implantação de um código de ética médica, como também os discursos sobre os procedimentos metodológicos universais ao conhecimento científico. A atual percepção social da ciência, que concilia representações opostas - a imagem de uma esfera distante, misteriosa e fechada, de um lado, e utilitária e iconoclasta, de outro - , foi elaborada e popularizada durante aquele período de construção de um monopólio legítimo de ação profissional.

A presença de uma forte tradição clínica na medicina brasileira oitocentista não constituiu uma barreira estrutural ao ingresso das novidades produzidas no terreno da experimentação. A clínica nutriu-se das conquistas alcançadas pela medicina experimental, ainda que inicialmente o tenha feito de forma passiva. A institucionalização da pesquisa experimental na esfera estatal não foi obra de um esforço demiúrgico de Oswaldo Cruz. Muito já havia sido feito pelos mestres da famosa geração de sanitaristas da República Velha através da última reforma do ensino superior no Império - Lei Leôncio de Carvalho (1879) - complementada pela gestão do visconde de Sabóia na Faculdade de Medicina da Corte (1880-89).

A década de 1870 marcou um momento de inflexão na trajetória da profissionalização da medicina acadêmica, com a elite médica do Império lutando pela redefinição do estatuto de cientificidade do saber médico, pela elaboração de um programa de pesquisas orientado para a nosologia e terapêtica nacionais, e pela emancipação da esfera destinada à formação profissional em relação à tutela exercida pela burocracia imperial (Edler, 1992).

$O$ processo de apropriação e institucionalização do arsenal técnico e teórico das disciplinas e dos modelos institucionais que revolucionaram a medicina em fins do século XIX dependeu, em larga medida, dos consensos e dissensos entre os próprios médicos em torno dos fundamentos epistemológicos de seu próprio saber, o que se expressou pelo debate em torno da noção de medicina experimental.

EDLER, F. C.: 'O debate em torno da medicina experimental no Segundo Reinado'. História, Ciências, Satide - Manguinhos, III (2):284-299, jul.-out. 1996.

A presença de uma forte tradição clínica na medicina oitocentista não constitui uma barreira estrutural ao ingresso das novidades produzidas no terreno da experimentação em laboratório, como afirmam 
alguns historiadores. $O$ amplo debate em torno das regras do 'método experimental' revela uma dimensão da luta travada entre adeptos de teorias médicas rivais, num contexto em que a dissensão entre os esculápios ameaçava sua autoridade científica, frente a outras categorias de curadores.

PALAVRAS-CHAVE: medicina experimental, história da medicina, história do Brasil.

\section{REFERÊNCIAS BIBLIOGRÁFICAS}

Fontes primárias

Documentos Oficias

Outras Fontes

Primârias

Benchimol, J. L.

mar.jun. 1995

Bernal, John D. 1976

Canguilhem, Georges 1977

Carvalho, M. A. R. de e Lima, N. V. T. 1992

Chalmers, Alan 1994
Discursos dos diretores da Faculdade de Medicina do Rio de Janeiro nos atos de formatura

José Martins da Cruz Jobim, 1863, R. M. I., 1864

Vicente Candido de Figueira Sabóia, 1883, R. M. I., 1884

Memórias históricas da Faculdade de Medicina do Rio de Janeiro

De 1854 a 1869, em Francisco Bruno Lobo, O ensino da medicina no Rio de Janeiro. Rio de Janeiro, Imprensa Nacional, vols. IV e V, 1969.

Imprensa Médica

Gazeta Médica do Rio de Janeiro (1862-64)

Revista Médica do Rio de Janeiro (1873-79)

Archivos de Medicina (1874)

Progresso Médico (1876-80)

União Médica (1881-84)

Gazeta Médica Brazileira (1882)

Annaes Braziliensis de Medicina (1884)

Conferências proferidas pelos médicos reformistas na Escola da Glória (1880) Carvalho, João Paulo de. 'Ensino superior. Ciência prática e experimental e laboratórios', em 15.8.1880. Jornal do Commercio, 16.8.1880.

Freitas, Cypriano de. 'Ensino superior. Fisiologia e patologia experimentais', em 26.8.1880. Jornal do Commercio, 28.8.1880

Teixeira, João Martins. 'Ensino superior. Faculdade de medicina, disciplinas e mestres', em 29.8.1880. Jornal do Commercio, 30.8.1880.

Figueiredo, C. A. Moncorvo de. Do exercicio e ensino médico no Brazil. Rio de Janeiro, Typ. Franco-Americana, 1874.

Lima, Agostinho J. de Souza. 'Discurso proferido na Sessão Magna Anniversaria da Academia Imperial de Medicina, em 30.6.1884', em Annaes Brazilienses de Medicina, tomo XXXVI, $\mathrm{n}^{2} 4$, out-dez. 1884.

'Domingos José Freire e os primórdios da bacteriologia no Brasil'. Em História, Ciências, Sauide - Manguinhos, II (1): pp. 67-98.

Ciência na história. Lisboa, Livros Horizonte, 5 vols.

Ideologia e racionalidade nas ciências da vida. Lisboa, Edições 70.

'O argumento histórico nas análises de saúde coletiva'. Em Fleury (org.), Sailde: coletiva? Questionando a onipotência do social. Rio de Janeiro, Relume-Dumará.

A fabricação da ciência. São Paulo, Unesp. 
Coni, Antonio Caldas 1952

Couty, Louis 1984

Derby, Orville A. nov. 1989

Edler, F. C. 1992

Fernandes, Reginaldo 1982

Ferreira, Luís Otávio 1996

Figueiredo, M. de 1874

Freire, Oscar 1968

Kuhn, Thomas S. 1987

Luz, Madel Terezinha 1982

Machado, Roberto et al. 1978

Medeiros, Maurício de 1953

Nava, Pedro 1949

Nava, Pedro 1947

Pires, Denise 1989

Santos Filho, Licurgo de Castro 1977

Stepan, N. 1976
A Escola Tropicalista Bahiana: Paterson, Wucherer, Silva Lima. Salvador, Tip. Beneditina.

O Brasil em 1884. Esboços sociológicos. Brasilia, MEC.

'O estado da ciência no Brasil', em Ciência Hoje, vol. 10, n² 59.

As reformas do ensino médico e a profissionalização da medicina na Corte do Rio de Janeiro: 1854-84. São Paulo, FFCL/USP. (mimeo.)

O conselheiro Jobim e o espirito da medicina de seu tempo.

Brasilia, Ed. do Senado Federal.

O nascimento de uma instituição científica: os periódicos médicos brasileiros da primeira metade do século XIX.

Tese de doutorado, FFLCH/USP, São Paulo. (mimeo.)

Do exercício ao ensino médico no Brazil.

Rio de Janeiro, Typ. Franco-Americana.

'Evolução da medicina no Brasil (1500-1922)'. Em Liçôes e conferências.

São Paulo, Fund. Vale Paraibana de Ensino, pp. 55-125.

'Las histórias de las ciencias: mundos diferentes para públicos distintos'.

Em Antônio Lafuente e Juan J. Saldaña, História de las ciências.

Madri, C. S. I. C., pp. 5-12.

Medicina e ordem política brasileira: 1850-1930. Rio de Janeiro, Graal.

Danação da norma. Rio de Janeiro, Graal.

'A evolução da medicina brasileira'. Em Aspectos da formação e evolução do Brasil. Rio de Janeiro, Jornal do Commercio.

Capítulos da bistória da medicina no Brasil.

Rio de Janeiro, Brasil Médico Cirúrgico.

Território de Epidautro. Rio de Janeiro, C. Mendes Junior.

Hegemonia médica na saíde e a enfermagem. São Paulo, Cortez.

História geral da medicina brasileira.

São Paulo, Edusp.

Gênese e evolução da ciência brasileira. Rio de Janeiro, Artenova. 